\title{
ÅTERFALLETS INVERKAN VID PÅFÖLJDSVAL OCH STRAFFMÄTNING
}

\author{
Av Pia RUdolFsSON
}

\section{INLEDNING}

Denna artikel behandlar förfarandet vid påföljdsval och straffmätning i den svenska brottmålsprocessen. Jag har valt att särskilt rikta in mig på de regler som stadgar att domstolen vid påföljdsval och straffmätning förutom omständigheterna kring själva gärningen även får ta hänsyn till att gärningen utgör återfall i brott. Här kommer jag att redogöra för hur den svenska lagstiftaren motiverar detta tillvägagångssätt.'

\section{REGLER OM ÅTERFALLSBROTTSLIGHET I DET SVENSKA PÅFÖLJDSSYSTEMET}

\section{$2.1 \mathrm{Nu}$ gällande återfallsbestämmelser i Brottsbalken $(\mathrm{Br} B)$}

Det faktum att ett brott utgör återfall får betydelse på olika sätt. Av $\operatorname{BrB} 26: 3$ framgår att ett återfall kan leda till straffskärpning i vissa fall. I 29:4 ges närmare föreskrifter för när detta får ske. Ett återfall kan, som nämnts ovan, få betydelse för påföljdsvalet; detta framgår av BrB 30:4 2 st, 30:10-11 och 31:1 2 st. Ett återfall påverkar också frågan om en villkorligt medgiven frihet skall förverkas enligt BrB 34:4 2 st. Även risken för återfall kan vara av betydelse för påföljdsvalet, nämligen då valet står mellan villkorlig dom och skyddstillsyn istället för fängelse, enligt BrB 30:7 och 30:9. Bestämmelserna i BrB kap 29 och 30 har tillkommit bl a för att öka förutsebarheten och enhetligheten eftersom rättsläget tidigare ansågs oklart avseende bedömningen av återfall. ${ }^{2}$

När de nya reglerna tillkom fanns det, uttalade departementschefen, behov av skärpta reaktioner mot återfallsbrottsligheten. Sådana skärpningar kan åstadkommas på tre sätt: genom val av svårare påföljd, genom förverkande av villkorligt medgiven frihet eller genom strängare straffmätning. ${ }^{3}$

Anledningen till att jag i fortsättningen behandlar de två huvudstadgandena $\mathrm{i}$ omvänd ordning är att bestämmelsen i 29:4 hänvisar till 30:4 varför det är naturligtatt först redogöra för huvudregeln.

\subsubsection{Nu gällande regler om påföljdsval vid återfall $i \mathrm{BrB} 30: 4$}

BrB 30:4 har följande lydelse:

»Vid val av påföljd skall rätten fästa särskilt avseende vid omständigheter som talar för en lindrigare påföljd än fängelse. Därvid skall rätten beakta sådana omständigheter som anges i 29 kap. 5 §. 
Som skäl för fängelse får rätten, utöver brottslighetens straffvärde och art, beakta att den tilltalade tidigare gjort sig skyldig till brott.«

Departementschefen uttalade i motiven att tidigare praxis skulle vara fortsatt vägledande även efter ändringarna i påföljdssystemet som trädde i kraft den 1 januari $1989^{4}$. När det gäller återfall i brott innebär det i huvudsak följande:

För bötesbrott medför återfall i likartad brottslighet successivt svårare straff; det innebär att skärpningen sker inom ramen för straffmätningen. När det däremot gäller fall där också fängelse ingår i straffskalan, i fall då brottet normalt föranleder bötesstraff, nås vid upprepade återfall i likartad brottslighet den gräns där rätten går över till att istället välja fängelse. I dessa fall leder alltså den skärpta straffmätningen till ett ändrat påföljdsval.

Av motivuttalandena framgår att även villkorlig dom kan komma i fråga som påföljd vid återfall. Det kan finnas fall där omständigheterna gör att förutsättningarna för att den tilltalade skall upphöra med fortsatt brottslighet framstår som goda, som $\mathrm{t}$ ex om den tilltalades sociala situation har förbättrats påtagligt eller om han/hon på annat sätt har förändrat sitt beteende så att återfallsrisken är mindre påtaglig. ${ }^{5}$

I de fall där den tidigare påföljden är skyddstillsyn, kan domstolen efter ett återfall skärpa påföljden genom att förena skyddstillsyn med böter eller ett kortare fängelsestraff. Att kombinera skyddstillsyn med fängelse är dock främst avsett för relativt allvarlig brottslighet. Om denna skärpning visar sig vara verkningslös återstår endast att döma till fängelse. Skulle nya återfall ändå uppstå kan förverkande av villkorligt medgiven frihet eller skärpt straffmätning komma i fråga.

Det finns inga generella riktlinjer för hur många domar som skall föreligga för att påföljden fängelse skall komma i fråga efter återfall. Istället är det faktorer som brottets art och svårhet och tiden mellan brotten som ges betydelse; gärningsmannens ålder beaktas också. De förhållanden som beaktas är alltså bland andra desamma som spelar in när domstolen skall bestämma om villkorligt medgiven frihet skall förverkas enligt $\mathrm{BrB} 34: 42$ st. $^{6}$

\subsubsection{Nu gällande regler om straffmätning vid återfall $i$ BrB 29:4}

BrB 29:4 har följande lydelse:

»Vid straffmätningen skall rätten, om förhållandet inte tillräckligt kan beaktas genom påföljdsvalet eller genom förverkande av villkorligt medgiven frihet, utöver brottets straffvärde, i skälig utsträckning ta hänsyn till om den tilltalade tidigare gjort sig skyldig till brott. Härvid skall särskilt beaktas vilken omfattning den tidigare brottsligheten haft, vilken tid som förflutit mellan brotten samt huruvida den tidigare och den nya brottsligheten är likartade eller brottsligheten i båda fallen är särskilt allvarlig.« 
Det återfallsgrundande brottet är det brott som den tilltalade tidigare har giort sig skyldig till och som han blivit dömd för eller som har lett till åtalsunderlåtelse eller strafföreläggande.

Vid återfall i bötesbrott sätts gränsen för straffskärpningen av det nya brottets straffmaximum. Det finns ingen särskild straffskala för återfall i bötesbrott.

När straffskalan innehåller både böter och fängelse kan däremot ett återfall eller upprepade återfall efter hand leda till att det inte anses tillräckligt att döma till böter.

De återfall som ger fängelsestraff kan vid ytterligare återfall medföra en skärpning av fängelsestraffet inom straffskalan. Straffhöjning kan också komma i fråga genom tillämpning av $\mathrm{BrB} 26: 3$ vid vissa grova brott (se nedan). ${ }^{7}$

I brottsbalken uppfattas numera återfall $\mathrm{i}$ brott som en i princip fristående omständighet som kan påverka straffmätningen och inte som en faktor som påverkar det nya brottets straffvärde. Departementschefen uttalade i motiven att detta inte utesluter att tidigare brottslighet kan bli av betydelse för bedömningen av det nya brottet t ex när det gäller att bestämma om detta är välplanerat eller hänsynslöst. ${ }^{8}$

Enligt 29:4 skall rätten ta hänsyn till återfall vid straffmätningen endast om detta inte har kunnat beaktas tillräckligt vid påföljdsvalet eller vid förverkande av villkorligt medgiven frihet. Det är främst i tre situationer som straffskärpning kan bli aktuell. Nämligen då:

1. tidigare straff inte har medfört någon villkorlig frigivning,

2. villkorlig frigivning har ägt rum men förverkande ändå är uteslutet, och

3. förverkande kan ske men inte är en tillräckligt ingripande skärpning. ${ }^{9}$

29:4 stadgar att man vid straffmätningen skall ta hänsyn till återfall i skälig utsträckning ; detta innebär att möjligheten till straffskärpning skall begagnas med viss försiktighet. När man tillämpar bestämmelsen i dessa fall skall följande grundläggande omständigheter tillmätas särskild betydelse:

1. den tidigare brottslighetens omfattning

2. den tid som har förflutit mellan brotten

3. förhållandet mellan brotten när det gäller art och svårhet.

När det gäller den tidigare brottslighetens omfattning kan sägas att behovet av straffskärpning anses särskilt starkt i samband med upprepade återfall. Det som är avgörande för om straffskärpning kommer i fråga är om punkt 2 eller 3 samtidigt föreligger. Ju allvarligare brottslighet det är fråga om, desto färre återfall behövs för att en straffskärpning skall vara motiverad. ${ }^{10}$ 
Avseende den tid som förflutit mellan brotten kan sägas att det finns större anledning att skärpa påföljden om återfallet sker inom kort tid än om det går lång tid innan det nya brottet begås. Om några år förflutit från den tidigare domen eller från frigivningen från ett frihetsstraff bör påföljden endast i undantagsfall påverkas av att det rör sig om ett återfall."

Om den sista punkten avseende förhållandet mellan brotten kan sägas att i de fall där det är fråga om likartade brott talar detta för att en skärpning av påföljden bör ske. Då det nya brottet avser en helt olikartad gärning är det inte passande att tala om återfall. Man måste dock väga detta mot om det nya brottet är lika grovt eller grövre än det tidigare. Om det nya brottet är grövre än det tidigare, är skälen för en skärpning starkare än om det rör sig om ett mindre allvarligt brott. ${ }^{12}$ Av HD-avgörandet NJA 1991 sid 498 framgår att HD vid straffmätningen tagit hänsyn till några av de ovannämnda omständigheterna.

I NJA 1991 sid 498 befanns den tilltalade, Slobodan S, vara skyldig till häleriförseelse, grov olovlig körning, ringa narkotikabrott och olaga vapeninnehav. Han hade i maj 1988 dömts för bland annat grovt narkotikabrott och olaga vapeninnehav till fängelse i 2 år och 6 månader. Han frigavs villkorligt från det straffet $i$ augusti 1989. I juni 1990 dömdes han återigen för bl a narkotikabrott och grov olovlig körning till fängelse i 8 månader, varvid den villkorligt medgivna friheten förklarades delvis föverkad. I januari 1991 blev han villkorligt frigiven från det sistnämnda straffet med en återstående strafftid av 8 månader.

De brott som är aktuella $\mathrm{i}$ fallet begicks endast ett par månader efter det att Slobodan S frigavs från det tidigare fängelsestraffet. HD uttalade att Slobodan S's snabba återfall och tidigare misskötsamhet talade för att den villkorligt medgivna friheten helt förverkats. HD lade emellertid vikt vid två andra omständigheter. Den första var att den tidigare och den nya brottsligheten inte var likartad ; straffet i juni 1990 avsåg narko tikabrott medan det nya avsåg olaga vapeninnehav. Den andra omständigheten som var av vikt var att den nya brottsligheten hade avsevärt lägre straff än vad Slobodan S ådömdes förra gången och att den nya brottsligheten alltså var av lindrigare slag än den tidigare.

HD förklarade därför endast 4 månader av den villkorligt medgivna friheten vara förverkad. Genom förordnandet om förverkandet av den villkorligt medgivna friheten ansåg HD att det faktum att brottet var ett återfall var tillräckligt beaktat $(\mathrm{BrB} 29: 4)$. HD uttalade att straffmätningen därför istället skulle ske med utgångspunkt $\mathrm{i}$ brottets straffvärde utan något hänsynstagande till att brottet var ett återfall. Slobodan S dömdes till fängelse i 4 månader.

Av propositionen framgår att tidigare praxis, trots de genomgripande ändringarna i påföljdssystemet, skall vara fortsatt vägledande ${ }^{13}$. Här nedan följer ett HDavgörande där likabehandlingsprinicpen vid straffmätning behandlas. 
I fallet NJA 1987 sid 459, som var ett resningsärende, hade en rådman misshandlat sin sambo. HD konstaterade att denna misshandel inte hade något samband med mannens yrkesbefattning. HovR hade i fallet låtit gärningsmannens yrkestillhörighet inverka på straffmätningen, HD uttalade dock att detta inte var förenligt med den likabehandlingsprincip som kommer till uttryck i RF 1:9. Det finns från allmän synpunkt behov av möjligheter att ingripa när en offentlig tjänsteman genom brott visar sig vara klart olämplig för sin befattning; även då brottet begåtts utom tjänsten. Sådana ingripanden kan emellertid komma till stånd genom exempelvis avskedande, denna sanktion beaktas också enligt BrB 29:5 1 st p 5. HD uttalade att det inte är förenligt med detta system att ytterligare skärpa straffet med hänsyn till tjänstemannens ställning, när denna inte har haft något samband med brottet. Detta skulle innebära dubbelbestraffning av det slag som ovannämnda regel avser att motverka. Resultatet kan också bli att de disciplinära myndigheterna får en missvisande bild av brottets svårhet. I målet beviljades inte resning, eftersom HD ansåg att HovR:s rättstillämpning inte stått i uppenbar strid med lag.

\subsubsection{Nu gällande regler om straffmätning vid återfall $i$ grov brottslighet $i$ Br.B 26:3} I BrB 26:3 finns en mer exakt formulerad regel som stadgar att domstolarna vid utdömandet av fängelsestraff kan överskrida straffmaximum när det gäller grova återfallsbrott. Regeln fanns tidigare fram till 1976 men upphävdes då eftersom lagstiftaren ansåg att det inte fanns något behov hos domstolarna att överskrida de straffmaxima som var stadgade för de särskilda brotten. ${ }^{14}$

Den nuvarande regeln tillkom 1981 i samband med att påföljden internering avskaffades. Internering som innehöll ett moment av långvarigt tidsobestämt frihetsberövande var avsedd för grov brottslighet. När denna påföljd skulle tas bort var det viktigt att se till att detta inte ledde till en lindring av samhällets reaktioner mot den allra grövsta kriminaliteten. Därför tillkom 26:3 för att domstolarna skulle ges möjlighet att döma till strafftider som nära anslöt till den praxis som fanns för sådana fall. Reglerna ansågs ge uttryck för de aktuella brottens straffvärde i en återfallssituation. ${ }^{15}$

BrB 26:3 är tillämplig på de fall där den tilltalade har dömts till minst två års fängelse och där det visar sig att återfallsbrottet är belagt med minst sex års fängelse. I ett sådant fall kan straffmaximum överstiga med högst fyra år det högsta straff som kan följa på återfallsbrottet eller återfallsbrotten (vid flera brott används $\mathrm{BrB}$ 26:2 för beräkning av straffmaximum). Lagregeln är fakultativ och även om förutsättningarna för regelns tillämpning är uppfyllda så är den straffskala som föreskrivs för brottet oftast fullt tillräcklig för att inrymma att brottet är ett återfall.

Departementschefen uttalade att det inte finns anledning att använda regeln om det är lång tid mellan det första brottet och återfallet och att en tillämpning av regeln främst kommer ifråga vid upprepade återfall ${ }^{16}$. I förarbetena uttalas att vid 
sidan av brottets allvar, antal och tidsmässiga relation bör hänsyn även tas till brottens karaktär. För att regeln skall tillämpas krävs alltså ett visst samband mellan den aktuella och den tidigare brottsligheten. Regeln bör härigenom inte tillämpas om brotten är av olika slag även om de enskilda brotten har ett mycket högt straffvärde. ${ }^{17}$ Fängelsestraffkommittén uttalade i sitt betänkande att fängelsestraffet vid ett återfall borde bestämmas utan hänsyn till tidigare brottslighet. Kommittén föreslog därför bl a att 26:3 skulle utgå. ${ }^{18}$ Denna uppfattning delade inte departementschefen. Hon menade att det $\mathrm{i}$ och för sig inte finns något underlag för att anta att ett längre fängelsestraff skulle kunna främja den dömdes anpassning $i$ samhället. Hon ansåg trots detta att det är naturligt att domstolarna särskilt vid återfall i synnerligen allvarlig brottslighet, kan markera det allvar med vilket samhället ser på den likgiltighet inför grundläggande värden som gärningsmannen har demonstrerat. ${ }^{19}$

Eftersom regeln endast avser själva bestämmningen av fängelsetidens längd kommer den inte att behandlas ytterligare.

\section{2 Återfallsbestämmelsernas utveckling}

Reglerna om påföljdsval och straffmätning genomgick senast en genomgripande ändring genom införandet av lag 1988:942 ${ }^{20}$. Lagförslaget som utarbetades av Fängelsestraff-kommittén kom bland annat att innebära att reglerna för påföljdsval och straffmätning som tidigare varit spridda över flera kapitel samlades i kapitel 29 och 30. Påföljdsutredningen som tillsattes 1990 lade i april 1991 fram ett betänkande med namnet Påföljdsfrågor ${ }^{21}$.

1992 tillsattes en parlamentarisk kommitté, Straffsystemkommittén, för översyn av påföljdssystemet. Av direktivet följer att kommittén bland annat skall utreda vilken betydelse återfall i brott skall tillmätas vid valet av påföljd och straffmätning $^{22}$. Kommittén förväntas avge sitt betänkande under 1995.

Sten Heckscher har i sin artikel »Fler i fängelse och längre straff - trendbrott i svensk kriminalpolitik? « bl a behandlat statsledningens reformiver avseende påföljdssystemet. Han skriver att det redan idag är så att återfall eller ej, är den viktigaste faktorn vid påföljdsbestämningen näst efter brottets grovhet. Den påverkar utomordentligt starkt, både val av påföljd och särskilt genom förverkanden av villkorligt medgiven frihet och straffets längd när fängelse döms ut. Han frågar om inte detta räcker, och undrar vad man vill vinna genom att ytterligare förstärka denna faktors betydelse. Heckscher anser att frågan om återfallets betydelse, genom den reform av reglerna för påföljdsval och straffmätning som trädde i kraft 1989, fick en välbalanserad lösning, utförligt argumenterad, som ger goda förutsättningar för en enhetlig och rättssäker tillämpning i domstolarna. Han anser således att det inte finns någon anledning att ytterligare förstärka återfallets betydelse vid påföljdsvalet och straffmätningen. ${ }^{23}$ 


\subsubsection{Fängelsestraffkommittén}

I anslutning till fängelsestraffkommitténs huvudbetänkande Påföljd för brott ${ }^{24} 1986$ har departementschefen uttalat att det vid påföljdsbestämningen måste finnas möjlighet att ta hänsyn till att det rör sig om återfall i brott. Det kan knappast sättas i fråga, säger hon, att det är av väsentlig betydelse för tilltron till påföljdssystemet att så får ske. Genom att successivt skärpa reaktionerna mot återfall bör samhället kunna markera att det är allvarligare med upprepad brottslighet än med enstaka brott. Hon antar också att en sådan ordning av en bred allmänhet uppfattas som naturlig och rimlig. ${ }^{25}$ Avseende tillämpningen av återfallsreglerna uttalade departementschefen att hon tar avstånd från att en »regelrätt« prognos läggs till grund för denna. Detta får emellertid inte tolkas så, noterar hon, att domstolarna skall avstå från att använda sig av de allmänna kunskaper om brottskarriärer, återfallsmönster eller effekter av olika påföljder som de besitter. Om det i ett visst fall föreligger omständigheter som allmänt sett talar för att förutsättningarna för återanpassning $\mathrm{i}$ samhället är goda, trots tidigare upprepad brottslighet, kan det utgöra ett skäl för att avstå från välja påföljden fängelse. Denna lösning kan också komma i fråga då en tilltalad har brutit mot ett tidigare livsmönster eller när hans sociala situation har förändrats på annat sätt. Då bör han/hon kunna ges den möjlighet som en icke frihetsberövande påföljd innebär, även om utsikterna att han/hon skall lyckas inte bedöms vara särskilt goda. ${ }^{26}$

Av NJA 1991 sid 359 framgår det att HD följer denna instruktion.

Fallet handlar om en person som trots att han hade återfallit i allvarlig trafikbrottslighet, i form av rattonykterhet i kombination med olovlig körning, dömts till skyddstillsyn. Skälen mot ett fängelsestraff ansågs vara så starka att den påföljden inte borde väljas. HD erinrade om att det var av stor vikt att det vid återfall, $\mathrm{i}$ enlighet med allmänna principer, bör gälla att påföljdsbestämningen endast $\mathrm{i}$ undantagsfall skall påverkas av den tidigare domen när det har gått några år från denna eller, i förekommande fall, från frigivningen av ett frihetsstraff. Av avgörande vikt var dock att den tilltalade, efter de senaste brotten cirka ett och ett halvt år före domen i HD, på eget initiativ hade underkastat sig rehabilitering med tillsynes gott resultat. Eftersom denna positiva utveckling skulle spolieras eller allvarligt äventyras om den tilltalade dömdes till fängelse, hänvisade $\mathrm{HD}$ till $\mathrm{BrB}$ 30:9 2 st p 1 och dömde den tilltalade till skyddstillsyn.

Motiven ger uttryck för en restriktiv syn på användningen av fängelsestraff. När några år har förflutit mellan en tidigare dom eller från frigivningen från ett frihetsstraff och ett nytt brott, bör påföljdsbestämningen endast i undantagsfall påverkas av att det rör sig om ett återfall. Det fastställs också att det skall föreligga skäl som med särskild styrka talar för att fängelse skall ådömas för att den påföljden skall få användas. ${ }^{27}$ 
Av NJA 1991 sid 379 framgår att tiden mellan brotten kan vara avgörande för påföljdsvalet.

I detta fall var det fråga om återfall i allvarlig trafiknykterhetsbrottslighet. Den till talade skulle dömas för två rattfylleribrott som ägt rum dels i maj, dels i juni 1989. Han hade dessförinnan i februari 1985 dömts till fängelse för rattfylleri. HD uttalade att påföljdsbestämningen i det här fallet inte skulle påverkas av den tidigare domen. Det avgörande var att den tid som förflutit mellan det tidigare och de aktuella brotten var något mer än fyra år.

\subsection{Kommentarer}

Suzanne Wennberg har i en artikel framfört kritik mot fängelsestraffkommitténs huvudbetänkande. Hon skriver att till grund för de förslag kommittén lägger fram angående påföljderna, straffskalorna och påföljdsbestämningen ligger en delvis förändrad syn på straffsystemets kriminalpolitiska funktion. Kommittén anser att huvudtanken bakom straffsystemet är att skydda samhället och medborgarna mot brott och att därför allmänpreventiva överväganden har grundläggande betydelse för beslutet om kriminalisering.

Brottens straffskalor skall enligt kommittén baseras på brottens svårhet eller förkastlighet och med detta avses att man bedömer vad brotten allmänt sett förtjänar för straff. Denna straffvärdebedömning grundas främst på den skada eller fara som brottet innebär i vid bemärkelse mot bakgrund av det värde eller intresse som skall skyddas. Hänsyn till de avskräckande eller moralbildande effekterna făr således inte medföra att straffskalan för ett visst brott sätts högre än vad förfarandets klandervärdhet påkallar. Denna princip används även vid påföljdsvalet och vid straffmätningen. Domstolarna, fortsätter Wennberg, skall därigenom inte tilImäta vare sig allmän- eller individualpreventiva hänsyn någon självständig betydelse i det enskilda fallet. Det var av denna anledning som Kommittén föreslog ett upphävande av $\operatorname{BrB}$ 1:7.

När det gäller återfallsbrottsligheten ifrågasätter Wennberg om kommittén tillämpar sina egna resonemang konsekvent. Hon anför: »trots att man anser att brottets svårhet skall ligga till grund för straffmätningen, föreslår kommittén att möjligheter ges till en strängare bedömning av återfallsbrottslighet, dvs en bedömning som är strängare än vad gärningens klandervärdhet påkallar.« Hon anför vidare: »Kommittén åberopar inte något principiellt skäl varför man överger det rättviseresonemang man annars propagerar för och låter allmän- och individualpreventiva synpunkter tillmätas avgörande betydelse just vid återfall.«

Kommittén har uttalat att det knappast torde finnas något rättssystem där inte tidigare domar för brott kan påverka påföljden för den nya brottsligheten. Wennberg uttalar: »Frågan om man i dessa rättssystem baserar straffmätningen uteslu- 
tande på brottets klandervärdhet besvaras dock inte. Det är svårt att dela kommitténs uppfattning att det oberoende av grundsyn skulle vara »självklart« att tidigare brottslighet bör påverka påföljdsbestämningen «. ${ }^{28}$

När brottsbalken kom 1965 trodde man starkt på förbättringsteorin; det var denna teori som skulle läggas till grund för påföljdsvalet, och fängelsestraffet skulle användas i minskad omfattning. Emellertid har teorin fått mycket kritik och numera är det värden som legalitet, rättvisa, proportionalitet mellan brott och påföljd och förutsebarhet som vunnit gehör i lagstiftningsarbetet. Denna nya strömning som i stora delar bygger på allmänpreventiva tankegångar kallas nyklassicism. ${ }^{29}$ Det råder emellertid delade meningar om vilket namn man kan sätta på den senaste teorin och vad den egentligen innebär i praktiken..$^{30}$

Personligen frågar jag mig hur lagstiftaren kan slå fast att domstolarna inte längre skall tillmäta preventionsteorierna någon betydelse, samtidigt som tidigare praxis skall vara fortsatt vägledande. Med två så olika system; där domstolarna i det gamla systemet särskilt tog individualpreventiva hänsyn (med oförutsägbar praxis som följd) och där domstolarna i det nya systemet skall tänka i termer av proportionalitet och ekvivalens, är det svårt att inse på vilket sätt tidigare praxis kan vara fortsatt vägledande.

\subsection{Straffteorierna - återfall}

Någon automatisk koppling mellan de olika straffteorierna och behandling av återfallsbrottslighet finns inte. Absoluta och relativa teorier, vedergällning, allmänprevention och individualprevention - i samtliga fall kan man tänka sig såväl att återfallet inte skall ha någon betydelse som att det skall påverka domslutet, argumentation kan framföras i såväl mildrande som skärpande riktning. Förutom teoriernas närmare utformning (om straffets eller straffsystemets ändamål etc) är också den uppfattning man har om straffets faktiska verkningar i olika hänseenden avgörande. Trots detta, kan det med hänsyn till det intresse det har för denna artikel, vara värt att nämna något om det samband som ändå finns mellan olika straffteorier och återfallsproblematiken.

Dag Victor skriver om detta i sin artikel »Återfallsregler i straffrätten« från 1975. Han går successivt igenom de olika teorierna och ser vilken betydelse återfallet tillmäts utifrån dessa. Ser man till de absoluta straffteorierna är det, enligt Victor, långt ifrån självklart att återfallen överhuvudtaget skall ha någon betydelse för straffrättskipningen. Det ligger nära till hands, skriver han, att anse att brottslingen genom straffet sonat sitt lagbrott och att detta därför inte skall påverka senare lagföring. Vedergällningstankegångar, i sin tur, är ofta så starkt knutna till brottets objektiva sida att återfallets skärpande verkan även då kan framstå som tveksam. I den mån man anser att återfallet ändå skall inverka är det naturligt att man avser att detta skall ske enligt fasta och klara regler. 
När det gäller allmänpreventiva utgångspunkter anser han att det skulle kunna hävdas att återfallsproblematiken inte var särskilt central. Vad man istället skulle ha anledning att inrikta sig på är medborgarna i allmänhet, medan återfallsproblematiken endast rör en liten grupp. Individualpreventionen (han bortser här från idéer om oskadliggörande och individuell avskräckning) kan knappast, som vid absoluta eller allmänpreventiva teorier, framstå som något i sig önskvärt - återfallet kan tjäna som en indikation på ett behandlingsbehov, men någon nödvändig relation mellan återfall och behandlingsbehov finns inte. Oavsett om återfall förligger bör man ha möjlighet att välja mellan olika påföljder, och vid straffmätning ha stor frihet att öka eller minska straffet beroende på omständigheterna i det enskilda fallet. ${ }^{31}$

Min reflektion efter att ha satt mig in i de ovannämnda teorierna är att det inte är lagstiftarens avsikt vid lagstiftningsögonblicket som blir avgörande för vilken teori som blir den gällande. Det är först $\mathrm{i}$ efterhand - när man ser hur lagstiftarens lösning fungerar i praktiken - som man kan uttala sig om vilken teori det är som blev resultatet. Samhällets reaktion mot återfallsbrottslighet innebär enligt bestämmelserna i BrB 29:4, 30:4 och 34:4 antingen skärpt straffmätning, strängare påföljd eller förverkande av villkorligt medgiven frihet. Om fångvårdssystemet som den dömde hamnar i fungerar väl med effektiv rehabilitering så är det, menar jag, förbättringsteorierna som är de gällande. Fungerar däremot systemet dåligt och fångvårdssystemet snarare bryter ner de intagna istället för att rehabilitera dem så är det istället oskadliggörandeteorierna som är de rådande; jag syftar här främst på inkapacitering. Har man ett system där fängelserna fungerar som brottsskolor blir ju effekten att den som en gång hamnat i fängelse, den kommer ständigt att göra återbesök.

Strafflagberedningen skrev i sin utredning 1953 det tänkvärda, att återfallet är »endast ett indicium på att det ingripande som gjorts misslyckats, när det gällt att förhindra fortsatt brottslighet ${ }^{32}$

Dag Victor skrev i »Straffsystemet under utveckling« 1984: »Lagöverträdaren ses som en i grunden avvikande person som skall behandlas för att återanpassas till samhället. Samhällets rätt och skyldighet att ingripa grundar sig på avvikelsen och inte på brottet. Straffet skall inte vara ett lidande utan något som hjälper och stöder den dömde - ett ingripande till hans eget bästa - eller om detta inte är möjligt - ett skydd för samhället. $\ll^{33}$

Trots att det är känt att höga eller stränga straff inte leder till minskad brottslighet använder man just högre eller strängare straff mot återfallsförbrytarna. ${ }^{34} \mathrm{De}$ fall där domstolarna låter återfall påverka påföljdsvalet och straffmätningen är när det är fråga om allvarlig brottslighet som upprepas. Därför är det främst påföljden fängelse som kommer ifråga som reaktion mot återfallsbrottslighet. Eftersom vårt 
fångvårdssystem inte är effektivt från rehabiliteringssynpunkt och återfallsförbrytarna för varje brott får längre fängelsestraff verkar det som om fängelserna används just som ett medel för att skydda samhället från brottslingarna, alltså för att inkapacitera brottslingarna.

\section{TIDIGARE BROTTSLIGHET - PLACERING I HUVUDFÖRHANDLINGEN}

Tidigare inledde man huvudförhandlingen i brottmål med att den tilltalades personalia lästes upp. Man kan lätt inse den förödande effekt detta måste ha haft för försvaret och den förledande effekt det måste ha haft på domstolen. Det slogs alltså fast, redan innan rätten hade hört den tilltalade, att det var en förtappad person de hade framför sig, en brottsling som redan tidigare visat sin oförmåga att följa samhällets lagar.

Numera har lagstiftaren ändrat på förfarandet. Den tilltalades personalia läses nu istället upp i förhandlingens slutskede, men fortfarande innan domstolen beslutar i skuld- och i påföljdsfrågan. Emellertid finns det fortfarande kvar spår av det gamla systemet såtillvida att åklagarna ofta under huvudförhandlingen anspelar på den tidigare brottsligheten i syfte att göra sin egen framställning av händelseförloppet mer trovärdig. Metoden utgör också ett skolexempel inom retoriken; att man utan att tala om vad man kommer att visa senare, talar om att man kommer att visa något. Man väcker på ett effektivt sätt lyssnarens intresse för vad som komma skall. Ett exempel på detta är då den tilltalade nekar till anklagelsen mot honom/henne och åklagaren kontrar med konstaterandet »nåja, det har ju faktiskt hänt tidigare att ni brustit på den punkten, det kommer att framgå senare i det här målet...... ${ }^{35}$

\section{AVSLUTANDE KOMMENTAR}

Enligt NJA 1987 sid 459 som jag behandlat i kapitel 2.1.2 stod det i strid med likabehandlingsprincipen i RF 1:9 att ta hänsyn till gärningsmannens tjänstebefattning vid straffmätningen. Man ansåg att detta kunde leda till en dubbelbestraffning eftersom den här typen av gärningsmän även får arbetsrättsliga påföljder för sitt brott.

När det gäller återfallsbrottslingar så talar man aldrig om likabehandlingsprinicp eller dubbelbestraffning. Men utgör det inte ett brott mot likabehandlingsprincipen att vissa brottslingar behandlas hårdare i våra domstolar? Och innebär det inte dubbelbestraffning att en brottsling som avtjänat sitt straff för ett begånget brott, om han begår brott igen, får svårare påföljd och strängare straff än förstagångsförbrytaren och därigenom straffas än en gång för det tidigare brottet?

Med hänsyn till att fängelsestraffet inte är någon effektiv påföljd bör det användas så lite som möjligt. Eftersom det har visat sig att inte bara inlåsning utan ock- 
så behandling fungerar dåligt är det angeläget att finna en helt ny form av påföljd. Jag är medveten om att den svenska lagstiftaren lägger ned stor möda på att finna en påföljd som kan ersätta fängelsestraffet. Så länge vi har kvar ett system där återfallsförbrytarna ytterst bara kan bestraffas med förlängt fängelsestraff och där denna bestraffning får effekten att de intagna blir mer brottsbenägna så ger det signalen att lagstiftaren har givit upp. Med hänsyn till både samhällsekonomiska och humanitära skäl är det därför viktigt att vi snabbt finner alternativa påföljder.

Departementschefen uttalar i direktiven ${ }^{36}$ till påföljdsutredningen att utredningen skall överväga möjligheterna att ge vissa intagna en gynnsammare behandling än andra. Hon ger som föreslag att främst förstagångsförbrytare och unga lagöverträdare skall särbehandlas när det gäller villkorlig frigivning.

Det här tror jag skulle innebära att man gav fel signaler. Man måste på något sätt få särskilt förstagångsförbrytare och unga lagöverträdare att inse att straff är något obehagligt, något som de sedan försöker undvika. Därför tror jag att man istället bör inrikta sig på obekväma straff för förstagångsförbrytarna och de unga lagöverträdarna; straff som verkligen är arbetssamma. Redan 1977 uttalade BRÅ i sin rapport Nytt straffsystem: »Rapporten talar för att man öppet erkänner att samhällets reaktioner på brott måste vara obehagliga för dem som utsätts för dem. De måste också präglas av regelmässighet och förutsägbarhet. Men detta behöver inte leda till strängare straff. Det borde vara lättare att humanisera kriminalpolitiken när man öppet erkänner att straff är obehagliga och sällan i den straffades intresse $\ll{ }^{37}$

En alternativ påföljd som blivit vanlig i andra länder är »medling«. Även om medlingsinstitutet företer diverse olikheter i skilda länder, innehåller det grundläggande gemensamma drag. I SOU 1993:53 uttalas att: »i flertalet länder består sanktionen i att gärningsmannen och brottsoffret sammanträffar inför en neutral person, en medlare, som står utanför det etablerade rättsväsendet, i syfte att ingå ett avtal. Avtalet har ofta den innebörden att gärningsmannen åtar sig att i någon form gottgöra brottsoffret för den skada som uppstått till följd av brottet,t ex genom att han åtar sig att betala skadestånd till målsäganden eller att utföra ett visst arbete för dennes räkning. Avtalet kan även bestå i att gärningsmannen helt enkelt ber brottsoffret om ursäkt.«

I Sverige pågår just nu en rad projekt där socialtjänst, polis och åklagare låter ungdomar som begått brott göra rätt för sig. Dessa åtgärder kommer till stånd på ett mycket tidigt stadium av det rättsliga förfarandet, och initiativet tas av polisen. Åtgärderna genomförs under samarbete mellan polisen och socialtjänsten. Om den unge gör rätt för sig resulterar förfarandet ofta $i$ en åtalsunderlåtelse. ${ }^{38}$

Jag anser alltså att man främst bör inrikta sig på förstagångsförbrytarna och de unga lagöverträdarna. Min bedömning är därför att medlingsinstitutet kan utgöra 
ett bra komplement; det är nyttigt för brottslingarna att träffa brottsoffren och verkligen se och höra vad de ställt till med. Det är i första hand förstagångsförbrytarna och de unga lagöverträdarna man måste avskräcka från att begå fler brott för att få en mer bestående minskning av återfallsbrottsligheten och av kriminaliteten i stort.

Det jag behandlat i denna artikel är främst hur den svenska lagstiftaren motiverar ett förfarande där man tar hänsyn till tidigare brottslighet vid påföljdsval och straffmätning. Den motivering som givits för användningen av förfarandet är att det för allmänheten skulle framstå som direkt stötande att vid utdömande av påföljd inte ta hänsyn till att ett brott utgör ett återfall. Under vissa perioder har det emellertid inte funnits några speciella återfallsbestämmelser utan domstolarna har fått hålla sig inom ramarna för de enskilda brottens straffskalor.

Personligen är jag inte motståndare till att återfall ger strängare straff. Att vi idag har påföljdstyper som i många fall gör de dömda till bättre brottslingar istället för till bättre medborgare anser jag däremot vara mycket olyckligt. Lagstiftaren bör, som jag anfört tidigare, anstränga sig för att finna alternativa påföljder som är mer effektiva från rehabiliteringssynpunkt. Jag har dock under arbetets gång insett att den lösning lagstiftaren till sist väljer i hög grad blir en politisk fråga.

För att alla skall få åtnjuta likabehandling i domstolarna vore det önskvärt om man kunde finna en annan lösning än den vi för närvarande har. Eftersom återfallsbestämmelserna främst kommer till användning vid grova återfallsbrott är det också fängelsestraff som är den vanligaste påföljden. För att få klara regler som även det aktuella »klientelet « känner till kan man istället låta själva verkställigheten påverkas av att det rör sig om ett återfall. Detta kan exempelvis ske genom att man inför ett system där alla som gjort sig skyldiga till återfall i brott automatiskt blir berövade möjligheten till villkorligt medgiven frihet; de får avtjäna hela det utdömda fängelsestraffet.

Att finna effektiva påföljder som ger en mer varaktig minskning av brottsligheten är således en fråga som jag anser måste placeras högt upp på regeringens dagordning. Med den 1992 tillsatta straffsystemkommittén verkar det emellertid som om statsledningen insett problemets allvar och aktivt försöker finna nya lösningar.

Adresse: Pia Rudolfsson

Västmannagatan 79,

S-113 26 Stockholm 


\section{Fotnoter}

1. Artikeln baseras på min examensuppsats i straffrätt på juristlinjen vid Stockholms Universitet. Uppsatsens titel är »Återfallets inverkan vid påföljdsval och straffmätning, enligt brottsbalken och enligt Europakonventionen för de mänskliga rättigheterna« (20 poäng) och skrevs under våren 1994. Min handledare har varit Professor Madeleine Leijonhufvud. Av utrymmesskäl behandlas i denna artikel bara de delar av uppsatsen som berör det svenska systemet.

2. Prop $1987 / 88: 120$ sid 50

3. Prop $1987 / 88: 120$ sid 53

4. Prop $1987 / 88: 120$ sid 54

5. Prop $1987 / 88: 120$ sid 104

6. Hoflund, O, Straff och andra reaktioner på brott, 3u, Stockholm 1993, sid 157

7. Hoflund sid 106 , se not $\mathrm{nr} 5$

8. Prop $1987 / 88: 120$ sid 56

9. Prop $1987 / 88: 120$ sid 57

10. Prop $1987 / 88: 120$ sid 89

11. Prop $1987 / 88: 120$ sid 53

12. Prop $1987 / 88: 120$ sid 53

13. Prop $1987 / 88: 120$ sid 38

14. SOU 1953:14 sid 143 och prop 1980/81:76 sid 79 ff

15. Prop $1980 / 81: 76$ sid $50 \mathrm{ff}$

16. Prop $1980 / 81: 76$ sid 58

17. Prop $1980 / 81: 76$ sid 58

18. SOU $1986: 14$ sid 426

19. Prop 1987/88:120 sid 52, 58

20. Prop 1987/88:120 sid 29, 30

21. SOU 1991:45

22. Direktiv $1992: 47$ sid 1

23. Heckscher, S, Svensk Juristtidning 1992 sid 121, sid 130 f

24. SOU 1986:13-15

25. Prop $1987 / 88: 120$ sid 52

26. Prop 1987/88:120 sid 55 och 104, se exempel på detta i NJA 1991 sid 359 (se sid 362)

27. Prop 1987/88:120 sid 101

28. Wennberg, S, Svensk Juristtidning 1986 sid 704, sid $704 \mathrm{ff}$

29. Elwing, CM, Aspelin, E \& Wallén, P-E, Brott och brottmål, 7u, Stockholm 1993, sid 160-162

30. Se exempelvis replikväxlingen mellan Leijonhufvud (eg Löfmarck) och von Hirsch, Jareborg samt Andenæs i Nordisk Tidsskrift for Kriminalvidenskab 1986 sid 49, 407-414, 1987 sid 300, 1988 sid 41, och 1989 sid 56.

31. Victor, D, Återfallsregler i straffrätten, Nordisk Tidsskrift for Kriminalvidenskab 1976 sid 249, se sid 253-254 32.SOU 1953:17 sid $141 \mathrm{f}$ 1976 sid 249 , se sid $253-25432$.SOU $1953: 17$ sid $141 \mathrm{f}$
33. Victor, D, Straffsystemet under utveckling, Kriminologi och kriminalpolitik, BR $\AA$ -
information $1984: 1$ sid 47-56, se sid 55

34. SOU 1986:14 sid 61

35. Ortmark, §, Maktens redskap, Malmö 1971, sid 181-182

36. Direktiv 1990:11

37. BRA $1977: 7$ sid 68

38. SOU 1993:35 sid 431 